\title{
JORGE, João Miguel Fernandes. Não é certo este dizer. Lisboa: Presença, 1997.
}

\author{
Edgard Pereira \\ Universidade Federal de Minas Gerais
}

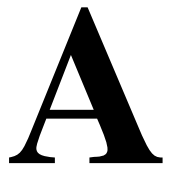

estréia poética de João Miguel F. Jorge se deu com Sob Sobre Voz (1971), com prefácio de Ruy Belo que destacava a importância daquela poesia, na linha dos melhores poetas de Poesia 61. Integrou o grupo de Cartucho (1976), publicação coletiva de poemas amassados jogados num saco de papel, ao lado de Antônio Franco Alexandre, Joaquim M. Magalhães e Hélder Moura Pereira. Autor de quatro livros de ficção e renomado crítico de artes plásticas, o título em epígrafe, entretanto, constitui seu vigésimo livro de poesia, na seqüência de um extenso e variado trabalho, referência compulsória para a compreensão da produção poética revelada em Portugal nas últimas três décadas.
Resultado deste rico trajeto, seu texto, atravessado pela ambigüidade e flutuações de sentido possibilitadas pela descontinuidade e ironia, revela uma síntese do rigor herdado dos anos 60 e da narratividade dos anos 80. O fascínio pelas ruínas e escombros, tanto de uma história coletiva como de uma memória individual desolada, associa-se a uma imprecisa e onipresente melancolia, esse triste fluir a que se chama memória, num discurso por vezes ironicamente próximo das modulações notariais da linguagem, ressaltando o aspecto pomposo e a quase banalidade dos feitos do passado. Nessa revisitação da história, a voz poética se projeta para uma antigüidade que se mostra terrivelmente contemporânea, numa concepção 
pós-moderna reveladora de uma irremediável fluidez entre o presente e o passado:

(...) Era alto e magro e dei com ele nos primeiros degraus da escadariado

[Colégio. Não

é dado a qualquer trazer até ao adro ondas do mar

de Nagazaki.

Tinha a voz treinada de um actor, era dono do timbre perfeito.

Hideyoshi, porém, decreta a expulsão

[da Companhia, decisão tomada enquanto bebia

[vinho da Bairrada. Crucificava as suas vítimas de pernas

[para o ar, em baixios que em breve a maré

[inundava.

("Incipit vita nova")

Purificada pelo fogo - a poesia de João Miguel F. Jorge foge à idéia de poesia como delicadeza (os professores e motoristas confundem poesia com delicadeza):

Sujeita os teus versos por brevíssimos [segundos

a uma chama: as marcas do fogo,

\{a coluna do fogo a fonte do fogo. A aceitação da cor, a aura azul \{é o rumor do amarelo.

("Eu sei")

Ostensivamente debruçada sobre a linguagem, a radicalidade desta poesia reside na criação de uma atmosfera fluida de mistério e ambigüidade, em que o sentido último (ou único) se esfuma diante da natureza fugidia de um dizer incerto palavras, obscuros traços que não entendo, e / a idéia de vir um dia a compreendê-los faz-me / tremer. O fantasma do desejo à deriva, tocado por uma aura de ascetismo e paixão, percorre inúmeros poemas, entre eles "Viviam num velho bairro de estudantes" e "In den Kasernen", de que se transcrevem alguns versos:

(...) O homem ia na rua escura.

[Chamava-os por um nome ao acaso Filipe Álvaro Jacinto Gabriel [João; preso de um modo doce à amargura que um \{nome sempre tem. Era ainda um homem muito novo, num [fato escuro mas um homem que trazia na voz a [velhice sábia dos engates. E os soldados armados do [quartel no centro da cidade passavam por detrás das [grades, entre as altas roseiras do jardim e o homem, indiferente aos que pudessem [cruzar com ele e mesmo aos que parassem [olhando-o reprovadoramente, ele estendia as mãos, apertava [com força as grades e dizia ao que estivesse mais [próximo 
"um broche em troca de uma dessas rosas [amarelas", como quem chama gatos atirando-lhes [uma sardinha fresca. (...)

Entre as inúmeras linhas de força deste dizer equivocado (a poesia é sempre um falar arrebatado) - as incursões pela história, a inquietação do desejo, as reflexões sobre a poesia, os desdobramentos da guerra colonial, a melancolia associada a meditações sobre a morte e a solidão, a busca de um sujeito intangível e sedutor, as descobertas das viagens e os reflexos da memória - a concepção de que a arte é uma sombra à beira do deserto confere um estatuto redentor ao trabalho poético. O poder de criar transforma-se numa nova transcendência, apesar do avassalador niilismo que banaliza quase todos os valores. Porque os políticos não são nada, porque / quem conduz o mundo são os deuses e a arte e a ciência; a / beleza e a vida. Este o fundamento grego desta poética, a crença na destinação órfica da existência. E para que se consolide, o intento criador necessita estruturar o universo, o que só se torna possível através do olhar voltado para a passagem do tempo: o verbo ver encerra a estrutura do mundo, a / ordem do tempo e a fragilidade dos vencidos. 